\title{
Effects of Carbohydrate and Dietary Fiber Intake, Glycemic Index and Glycemic Load on HDL Metabolism in Asian Populations
}

\author{
Hidekatsu Yanai ${ }^{\mathrm{a}, \mathrm{c}}$, Hisayuki Katsuyama ${ }^{\mathrm{a}}$, Hidetaka Hamasaki ${ }^{\mathrm{a}}$, \\ Shinichi Abe ${ }^{\mathrm{b}}$, Norio Tada ${ }^{\mathrm{b}}$, Akahito Sako ${ }^{\mathrm{a}}$
}

\begin{abstract}
High-density lipoprotein (HDL) is a lipoprotein which has antiatherogenic property by reverse cholesterol transport from the peripheral tissues to liver. Low HDL-cholesterol (HDL-C) levels are associated with the development of coronary artery diseases (CADs). Various epidemiological studies have suggested that the development of CAD increase in individuals with less than $40 \mathrm{mg}$ / $\mathrm{dL}$ of HDL-C. In spite of accumulation of evidences which suggest a significant association between low HDL-C and cardiovascular diseases, effects of dietary factors on HDL metabolism remained largely unknown. There may be interracial differences in effects of dietary factors on HDL metabolism. Here we reviewed published articles about effects of carbohydrate and dietary fiber intake, glycemic index (GI) and glycemic load (GL), on HDL-C metabolism, regarding meta-analyses and clinical studies performed in Asian population as important articles. Low carbohydrate intake, GI and GL may be beneficially associated with HDL metabolism. Dietary fiber intake may be favorably associated with HDL metabolism in Asian populations.
\end{abstract}

Keyword: Carbohydrate; Dietary fiber; Glycemic index; Glycemic load; High-density lipoprotein

\section{Introduction}

High-density lipoprotein (HDL) plays a role in reverse cholesterol transport from the peripheral tissues to liver, suppressing cholesterol accumulation in the peripheral tissue.

\footnotetext{
Manuscript accepted for publication June 27, 2014

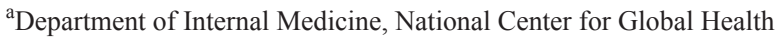
and Medicine Kohnodai Hospital, Chiba, Japan

${ }^{\mathrm{b}}$ The Jikei University School of Medicine, Tokyo, Japan

${ }^{\mathrm{c}}$ Corresponding Author: Hidekatsu Yanai, Department of Internal

Medicine, National Center for Global Health and Medicine Kohnodai

Hospital, 1-7-1 Kohnodai, Chiba 272-8516, Japan.

Email: dyanai@hospk.ncgm.go.jp
}

doi: http://dx.doi.org/10.14740/jocmr1884w
Since HDL is a lipoprotein which has anti-atherogenic property, low HDL-cholesterol (HDL-C) level induces the development of coronary artery diseases (CADs), and high HDL$\mathrm{C}$ level is associated with reduction of incidence of CAD [1, 2]. Various epidemiological studies have suggested that the development of CAD increase in individuals with less than $40 \mathrm{mg} / \mathrm{dL}$ of HDL-C [1, 3-5]. In a large scale cohort study of the relationship between serum cholesterol concentration and coronary events with low-dose simvastatin therapy in Japanese patients with hypercholesterolemia, there was higher mortality in patients with an HDL-C concentration $<40 \mathrm{mg} / \mathrm{dL}$ compared with those whose average HDL-C concentration was between 40 and $49 \mathrm{mg} / \mathrm{dL}$ by $30 \%$ [6]. According to these data, low HDL-C was defined as HDL$\mathrm{C}$ concentration $<40 \mathrm{mg} / \mathrm{dL}$ in Japan. Low HDL-C is also associated with cerebrovascular diseases (CVDs), and HDL$\mathrm{C}$ levels were inversely correlated with the development of death due to CVD [7].

In spite of accumulation of the data suggesting a significant influence of low HDL-C on CAD and CVD, effects of dietary factors on HDL-C remained unknown. We should also consider the existence of interracial differences in effects of dietary factors on HDL metabolism. Here we reviewed published articles about effect of dietary factors, especially, carbohydrate and dietary fiber intake, glycemic index (GI) and glycemic load (GL), on HDL metabolism. We regarded systematic review and meta-analysis and also clinical studies which were performed in Asian populations as important articles in this review.

\section{Effects of Carbohydrate Intake on HDL-C}

The meta-analysis demonstrated that the low-carbohydrate diet (energy from carbohydrate $\leq 45 \%$ of total energy) increased HDL-C by $3.3 \mathrm{mg} / \mathrm{dL}$ as compared with the low fat diet (energy from fat $\leq 30 \%$ of total energy) [8] (Table 1). In the meta-analysis investigating the association between the intake of diet including milk fat and coronary risk factors, the substituting saturated fat from whole milk and butter for carbohydrate or unsaturated fatty acids increased HDL-C [9]. Hession et al performed the meta-analysis for compari- 
Table 1. Meta-Analysis and Systematic Reviews About Effects of Carbohydrate Intake on HDL-C

\begin{tabular}{|c|c|c|c|}
\hline Authors & Study design & Subjects studied & Results/conclusions \\
\hline Hu et al [8] & $\begin{array}{l}\text { Low-carbohydrate diets } \\
(\leq 45 \%) \text { vs. low-fat diets } \\
(\leq 30 \%) \text { on metabolic risk } \\
\text { factors }\end{array}$ & 2,788 participants & $\begin{array}{l}\text { Compared with low-fat diets, low- } \\
\text { carbohydrate diets induced a greater } \\
\text { increase in HDL-C }(3.3 \mathrm{mg} / \mathrm{dL} ; 95 \% \\
\text { CI, } 1.9-4.7)\end{array}$ \\
\hline Huth et al [9] & $\begin{array}{l}\text { The relationship between } \\
\text { milk fat containing dairy } \\
\text { foods and cardiovascular } \\
\text { risk factors }\end{array}$ & & $\begin{array}{l}\text { A diet higher in saturated fat from } \\
\text { whole milk and butter increase HDL-C } \\
\text { when substituted for carbohydrates or } \\
\text { unsaturated fatty acids }\end{array}$ \\
\hline Hession et al [10] & $\begin{array}{l}\text { Low-carbohydrate diets } \\
\text { vs. low-fat/low-calorie } \\
\text { diets }\end{array}$ & $\begin{array}{l}\text { Adults with } \mathrm{BMI} \geq 28 \mathrm{~kg} / \\
\mathrm{m}^{2}\end{array}$ & $\begin{array}{l}\text { There were significant differences } \\
\text { between the groups for HDL-C, } \\
\text { favoring the low-carbohydrate diet }\end{array}$ \\
\hline Crawford et al [11] & $\begin{array}{l}\text { Systemic review on } \\
\text { dietary factors on } \\
\text { metabolic parameters }\end{array}$ & & $\begin{array}{l}\text { Low-carbohydrate diets raise HDL-C } \\
\text { by approximately } 10 \%\end{array}$ \\
\hline Kodama et al [12] & $\begin{array}{l}\text { Influence of fat and } \\
\text { carbohydrate proportions } \\
\text { on metabolic parameters }\end{array}$ & $\begin{array}{l}306 \text { patients with type } 2 \\
\text { diabetes }\end{array}$ & $\begin{array}{l}\text { LFHC diet significantly lowered } \\
\text { HDL-C by } 6 \%(P<0.001) \text { compared } \\
\text { with HFLC diet }\end{array}$ \\
\hline Nordmann et al [13] & $\begin{array}{l}\text { Low-carbohydrate } \\
\text { vs. low-fat diets on } \\
\text { cardiovascular risk } \\
\text { factors }\end{array}$ & 447 individuals & $\begin{array}{l}\text { HDL-C changed more favorably } \\
\text { in individuals assigned to low- } \\
\text { carbohydrate diets after } 6 \text { months by } \\
4.6 \mathrm{mg} / \mathrm{dL}(95 \% \mathrm{CI}, 1.5-8.1)\end{array}$ \\
\hline Mensink et al [14] & $\begin{array}{l}\text { Effect of changes in } \\
\text { carbohydrate and fatty } \\
\text { acid intake on serum lipid } \\
\text { and lipoprotein levels }\end{array}$ & 27 controlled trials & $\begin{array}{l}\text { All fatty acids elevated HDL-C when } \\
\text { substituted for carbohydrates }\end{array}$ \\
\hline
\end{tabular}

BMI: body mass index; HDL-C: high-density lipoprotein-cholesterol; HFLC: high-fat low-carbohydrate; LFHC: low-fat highcarbohydrate.

son between low-carbohydrate diets and low-fat/low-calorie diets [10]. In this study, adult populations with mean or median body mass index $(\mathrm{BMI}) \geq 28 \mathrm{~kg} / \mathrm{m}^{2}$ were included as participants studied. There were significant differences between the groups for HDL-C, favoring the low-carbohydrate diet. In the systematic review by Crawford et al, the low-carbohydrate diets raised HDL-C by approximately $10 \%$ [11]. The meta-analysis was also performed to elucidate the effect of replacing dietary fat with carbohydrate on glucose and lipid metabolism in patients with type 2 diabetes. This metaanalysis including 19 randomized trials $(n=306)$ investigated the effects of a low-fat, high-carbohydrate (LFHC) diet and a high-fat, low-carbohydrate (HFLC) diet [12]. Median diet compositions of carbohydrate/fat in the LFHC and HFLC diets were 58\%/24\% and 40\%/40\%, respectively. The LFHC diet significantly lowered HDL-C by $6 \%(\mathrm{P}<$ $0.001)$ compared with the HFLC diet. Nordmann et al used the Cochrane Collaboration search strategy to identify trials comparing the effects of low-carbohydrate diets without restriction of energy intake vs. low-fat diets in individuals with a BMI of at least $25 \mathrm{~kg} / \mathrm{m}^{2}$ [13]. Five trials including a total of 447 individuals fulfilled the study inclusion criteria. After 6 months, HDL-C changed more favorably in individuals assigned to the low-carbohydrate diets as compared with the low-fat diets. Weighted mean difference for HDL-C was 4.6 $\mathrm{mg} / \mathrm{dL}(95 \% \mathrm{CI} ; 1.5-8.1 \mathrm{mg} / \mathrm{dL})$. Mensink et al calculated the effect of changes in carbohydrate and fatty acid intake on serum lipids, reviewing 27 controlled trials published be- 
Table 2. Clinical Trials to Study Effects of Dietary Fiber Intake on HDL-C, Performed in Asian Populations

\begin{tabular}{|c|c|c|c|c|}
\hline Authors & $\begin{array}{l}\text { Nationality of } \\
\text { subjects }\end{array}$ & Study design & Subjects studied & Results/conclusions \\
\hline Zhang et al [18] & China & $\begin{array}{l}\text { Daily } 100 \mathrm{~g} \text { of instant } \\
\text { oat cereal vs. } 100 \mathrm{~g} \\
\text { of wheat flour-based } \\
\text { noodles for } 6 \text { weeks }\end{array}$ & $\begin{array}{l}\text { Adults with mild } \\
\text { to moderate } \\
\text { hypercholesterolemia }\end{array}$ & $\begin{array}{l}\text { HDL-C decreased } \\
\text { significantly in the control } \\
\text { group vs. the oat group }\end{array}$ \\
\hline Singh et al [19] & India & $\begin{array}{l}\text { Soluble dietary fiber } \\
\text { and a potassium-rich } \\
\text { diet containing } 0.5 \text { - } \\
1.0 \mathrm{~kg} \text { of guava daily } \\
\text { (group A) vs. an usual } \\
\text { diet (group B) for } 4 \\
\text { weeks }\end{array}$ & 145 hypertensive patients & $\begin{array}{l}\text { An insignificant increase in } \\
\text { HDL-C }(4.6 \%) \text { with a mild } \\
\text { increase in TC/ HDL-C in } \\
\text { group A patients compared } \\
\text { with group B }\end{array}$ \\
\hline Singh et al [20] & India & $\begin{array}{l}\text { Guava fruit preferably } \\
\text { before meals in a } \\
\text { foods-to-eat approach } \\
\text { rather than foods- } \\
\text { to-restrict, in a } \\
\text { randomized and single- } \\
\text { blind fashion for } 12 \\
\text { weeks }\end{array}$ & $\begin{array}{l}120 \text { patients with essential } \\
\text { hypertension }\end{array}$ & $\begin{array}{l}\text { A significant net increase } \\
\text { in HDL-C }(8.0 \%) \text { after } \\
12 \text { weeks of guava fruit } \\
\text { substitution }\end{array}$ \\
\hline Zhang et al [21] & China & $\begin{array}{l}\text { An ordinary diet plus } \\
\text { foods containing } \\
\text { refined konjac meal vs. } \\
\text { the ordinary diet for } \\
45 \text { days }\end{array}$ & $\begin{array}{l}110 \text { elderly people with } \\
\text { hyperlipidemia }\end{array}$ & $\begin{array}{l}\text { In the experimental group, } \\
\text { HDL-C was significantly } \\
\text { elevated }(\mathrm{P}<0.01) \text {. In the } \\
\text { control group, the change in } \\
\text { HDL-C was insignificant. } \\
\text { The difference in HDL-C } \\
\text { between the two groups was } \\
\text { statistically significant }\end{array}$ \\
\hline
\end{tabular}

HDL-C: high-density lipoprotein-cholesterol; TC: total cholesterol.

tween 1970 and 1991 [14]. They found that all fatty acids elevated HDL-C when substituted for carbohydrates.

In spite of accumulation of such as meta-analysis, evidence obtained from clinical trials performed in Asian populations is very limited. We found the clinical study performed by Miyashita et al in Japan [15]. They investigated the effects of low-carbohydrate diet on glucose and lipid metabolism in obese subjects with type 2 diabetes. Subjects studied were randomly assigned to take a low-calorie and low-carbohydrate diet $(\mathrm{n}=11,1,000 \mathrm{kcal}$ per day, protein:carbohydrate:fat $=25: 40: 35)$ or a low-calorie and high-carbohydrate diet $(\mathrm{n}=$ $11,1,000 \mathrm{kcal}$ per day, protein:carbohydrate: $\mathrm{fat}=25: 65: 10$ ) for 4 weeks. HDL-C increased in the low-carbohydrate diet group but not in the high-carbohydrate diet group $(+15 \%$ vs. $0 \%, \mathrm{P}<0.01)$.
Evidences obtained from meta-analyses/systematic reviews and clinical trials in Asian populations strongly suggest that low-carbohydrate intake is beneficially associated with HDL-C metabolism.

\section{Effects of Dietary Fiber Intake on HDL-C}

Talati et al performed a systematic literature search to determine the association between consumption of barley and changes in plasma lipids in healthy and hypercholesterolemic men and women [16]. They found eight trials $(n=391)$ of 4 - 12 weeks' duration evaluating the lipid-reducing effects of barley. The use of barley did not appear to significantly alter HDL-C $(\mathrm{P}=0.07)$, concluding that barley-derived beta- 
Table 3. Clinical Trials to Study Effects of GI and GL on HDL-C, Performed in Asian Populations

\begin{tabular}{|c|c|c|c|c|}
\hline Authors & $\begin{array}{l}\text { Nationality of } \\
\text { subjects }\end{array}$ & Study design & Subjects studied & Results/conclusions \\
\hline Choi et al [28] & Korea & $\begin{array}{l}\text { The association } \\
\text { between dietary } \\
\text { carbohydrates } \\
\text { and low HDL-C } \\
\text { prevalence }\end{array}$ & $\begin{array}{l}\text { A total of } 9,947 \\
\text { Korean adults older } \\
\text { than } 20 \text { years }\end{array}$ & $\begin{array}{l}\text { Odds ratios for having low } \\
\text { HDL-C in the highest quintile } \\
\text { were } 1.66(95 \% \mathrm{CI}, 1.24-2.22) \\
\text { for total carbohydrate, } 1.34 \\
(1.02-1.75) \text { for percentage of } \\
\text { energy from carbohydrate, and } \\
1.54(1.17-2.03) \text { for GL in men } \\
\text { as compared with the second } \\
\text { quintile as a reference. Odds ratio } \\
\text { for low HDL-C was } 1.38(1.12 \\
-1.71) \text { for percentage of energy } \\
\text { from carbohydrate in women. }\end{array}$ \\
\hline $\begin{array}{l}\text { Murakami et al } \\
{[29]}\end{array}$ & Japan & $\begin{array}{l}\text { The associations } \\
\text { between dietary } \\
\text { GI and GL and } \\
\text { metabolic risk } \\
\text { factors }\end{array}$ & $\begin{array}{l}\text { 1,354 Japanese female } \\
\text { farmers aged } 20-78 \\
\text { years from five regions } \\
\text { of Japan }\end{array}$ & $\begin{array}{l}\text { Dietary GL was independently } \\
\text { negatively correlated with HDL-C } \\
(\mathrm{n}=1,354 ; \mathrm{P}=0.004)\end{array}$ \\
\hline $\begin{array}{l}\text { Amano et al } \\
{[30]}\end{array}$ & Japan & $\begin{array}{l}\text { The associations } \\
\text { between dietary } \\
\text { GI, GL and CVD } \\
\text { risk factors }\end{array}$ & $\begin{array}{l}\text { A total of } 32 \text { women } \\
\text { aged } 52.5 \pm 7.2 \text { years } \\
\text { participated in the } \\
\text { weight-reduction } \\
\text { program }\end{array}$ & $\begin{array}{l}\text { In the lowest GI tertile, the } \\
\text { highest concentration of HDL-C } \\
\text { was observed }(\mathrm{P}<0.01) \text {. In the } \\
\text { lowest GL tertile, the highest } \\
\text { concentration of HDL-C was } \\
\text { observed }(\mathrm{P}<0.05)\end{array}$ \\
\hline
\end{tabular}

Cl: confidence interval; CVD: cardiovascular disease; GI: glycemic index; GL: glycemic load; HDL-C: high-density lipoproteincholesterol.

glucan appears not to affect HDL metabolism. Anderson et al reviewed international nutrition recommendations with a special emphasis on carbohydrate and dietary fiber in individuals with diabetes mellitus [17]. For diabetic subjects, the moderate carbohydrate and high-fiber diets compared to the moderate carbohydrate and low-fiber diets are associated with significantly lower values for HDL-C. The highcarbohydrate and high-fiber diets compared to the moderatecarbohydrate and low-fiber diets are associated with lower values for HDL-C.

Several clinical trials to study effects of dietary fiber on HDL-C were performed in Asian populations (Table 2). Zhang et al investigated the impact of oat consumption on cholesterol levels in Chinese adults with mild to moderate hypercholesterolemia [18]. The oat group consumed $100 \mathrm{~g}$ of instant oat cereal versus the control group who consumed $100 \mathrm{~g}$ of wheat flour-based noodles daily for 6 weeks. Dietary fiber intake increased significantly in the oat group compared to the control group at the end of the 6-week inter- vention. HDL-C decreased significantly in the control group versus the oat group. Singh et al performed a randomized, single-blind, controlled trial to examine the effects of guava fruit intake in patients with essential hypertension [19]. Seventy-two patients were assigned to take a soluble fiber and a potassium-rich diet containing daily $0.5-1.0 \mathrm{~kg}$ of guava (group A) and 73 patients to their usual diet (group B). After 4 weeks of follow-up, increased intake of soluble dietary fiber was associated with an insignificant increase in HDL-C (4.6\%). They performed another study. Sixty-one and 59 patients with essential hypertension were administered guava fruit preferably before meals in a foods-to-eat (group A) approach rather than foods-to-restrict (group B), respectively, in a randomized and single-blind fashion for 12 weeks [20]. There was a significant net increase in HDL-C $(8.0 \%)$ after 12 weeks of guava fruit ingestion. In the study by Zhang et al, a total of 110 elderly people with hyperlipidemia were randomly assigned to the experimental group who consumed an ordinary diet plus foods containing refined konjac meal, 
and the control group who consumed only the ordinary diet for 45 days [21]. At the end of the trial, HDL-C significantly elevated $(\mathrm{P}<0.01)$ in the experimental group.

According to results by meta-analyses, we could not determine whether dietary fiber intake is beneficially associated with HDL-C metabolism, or not. Evidences obtained from clinical trials performed in Asian populations suggest that dietary fiber intake may be beneficially associated with HDL-C metabolism. However, we should perform further studies to understand whether dietary fiber intake is correlated with elevation of HDL-C independently of other nutrients such as carbohydrate and vitamins.

\section{Effects of GI and GL on HDL-C}

Recently, the role of GI and GL in the healthy state, in prediabetic and diabetic state has been discussed [22]. Carbohydrate-rich foods are classified on the basis of their effects on postprandial glucose excursion, as indicated by their GI, which is calculated by dividing the incremental area under the curve of blood glucose concentrations measured after the ingestion of a portion of a test food containing $50 \mathrm{~g}$ carbohydrate by the incremental blood glucose area achieved with a portion of a reference food, and expressed as a percentage [23]. Although dietary fiber is not always associated with low GI, dietary fiber-rich foods generally have a low GI [24, 25]. Postprandial blood glucose levels are influenced not only by GI, but also the amount of carbohydrate intake. Therefore, the GL which is calculated by the GI (amount of carbohydrate contained in food) has been developed to better represent both the quantity and the quality of the carbohydrate intake [26].

Goff et al conducted the meta-analysis of randomized controlled trials of low-GI diets on blood lipids, by using OVID Medline, Embase and Cochrane library [27]. Random effects meta-analyses were performed on 28 trials comparing low- with high-GI diets over at least 4 weeks $(\mathrm{n}=1,272)$. There were no effects of low-GI diets on HDL-C.

Three cross-sectional studies to investigate effects of GI and GL on HDL-C were performed in Asian populations (Table 3). Choi et al studied the association between dietary carbohydrate and low HDL-C prevalence in Korean adults ( $\mathrm{n}=9,947)$, using the data from the Fourth Korea National Health and Nutrition Examination Survey [28]. Total carbohydrate intake (g/day), percentage of energy from carbohydrate, GI and GL were divided into quintiles. Odds ratios for having low HDL-C in the highest quintile were $1.66(95 \%$ CI, 1.24 - 2.22) for total carbohydrate, 1.34 (1.02 - 1.75) for percentage of energy from carbohydrate, and 1.54 (1.17 2.03) for GL in men as compared with the second quintile as a reference. Odds ratio for low HDL-C was 1.38 (1.12 - 1.71) for percentage of energy from carbohydrate in women. Low HDL-C is associated with high-carbohydrate intake without regard to energy or fat intake in Korean population. Muraka$\mathrm{mi}$ et al examined the cross-sectional associations between dietary GI and GL and metabolic risk factors in healthy Japanese women $(n=1,354)$ [29]. Dietary GL was independently negatively correlated with HDL-C. Amano et al studied the correlation between dietary GI, GL and CVD risk factors in 32 Japanese women aged $52.5 \pm 7.2$ years old [30]. In the lowest GI tertile, the highest concentration of HDL-C was observed $(\mathrm{P}<0.01)$. In the lowest GL tertile, the highest concentration of HDL-C was observed $(\mathrm{P}<0.05)$.

Based on the data obtained from clinical trials performed in Asian populations, low GI and low GL may be beneficially associated with HDL metabolism.

\section{Conflict of Interests}

The authors declare that they have no competing interests.

\section{Funding}

This work was funded by a grant from the National Center for Global Health and Medicine (25-203).

\section{References}

1. Kitamura A, Iso H, Naito Y, Iida M, Konishi M, Folsom AR, Sato $S$, et al. High-density lipoprotein cholesterol and premature coronary heart disease in urban Japanese men. Circulation. 1994;89(6):2533-2539.

2. Yokokawa H, Yasumura S, Tanno K, Ohsawa M, Onoda T, Itai K, Sakata K, et al. Serum low-density lipoprotein to high-density lipoprotein ratio as a predictor of future acute myocardial infarction among men in a 2.7-year cohort study of a Japanese northern rural population. J Atheroscler Thromb. 2011;18(2):89-98.

3. Satoh H, Nishino T, Tomita K, Saijo Y, Kishi R, Tsutsui $\mathrm{H}$. Risk factors and the incidence of coronary artery disease in young middle-aged Japanese men: results from a 10-year cohort study. Intern Med. 2006;45(5):235-239.

4. Maruyama K, Hirobe K, Noda H, Iso H, Dohi S, Terai T, Fujioka S, et al. Associations between blood lipid profiles and risk of myocardial infarction among Japanese male workers: $3 \mathrm{M}$ Study. J Atheroscler Thromb. 2009;16(6):714-721.

5. Noda H, Iso H, Saito I, Konishi M, Inoue M, Tsugane $\mathrm{S}$, Group JS. The impact of the metabolic syndrome and its components on the incidence of ischemic heart disease and stroke: the Japan public health center-based study. Hypertens Res. 2009;32(4):289-298.

6. Matsuzaki M, Kita T, Mabuchi H, Matsuzawa Y, Nakaya N, Oikawa S, Saito Y, et al. Large scale cohort study 
of the relationship between serum cholesterol concentration and coronary events with low-dose simvastatin therapy in Japanese patients with hypercholesterolemia. Circ J. 2002;66(12):1087-1095.

7. Okamura T, Hayakawa T, Kadowaki T, Kita Y, Okayama A, Ueshima H, Group NDR. The inverse relationship between serum high-density lipoprotein cholesterol level and all-cause mortality in a 9.6-year follow-up study in the Japanese general population. Atherosclerosis. 2006;184(1):143-150.

8. Hu T, Mills KT, Yao L, Demanelis K, Eloustaz M, Yancy WS, Jr., Kelly TN, et al. Effects of low-carbohydrate diets versus low-fat diets on metabolic risk factors: a meta-analysis of randomized controlled clinical trials. Am J Epidemiol. 2012;176 (Suppl 7):S44-54.

9. Huth PJ, Park KM. Influence of dairy product and milk fat consumption on cardiovascular disease risk: a review of the evidence. Adv Nutr. 2012;3(3):266-285.

10. Hession M, Rolland C, Kulkarni U, Wise A, Broom J. Systematic review of randomized controlled trials of low-carbohydrate vs. low-fat/low-calorie diets in the management of obesity and its comorbidities. Obes Rev. 2009;10(1):36-50.

11. Crawford P, Paden SL, Park MK. Clinical inquiries: What is the dietary treatment for low HDL cholesterol? J Fam Pract. 2006;55(12):1076-1078.

12. Kodama S, Saito K, Tanaka S, Maki M, Yachi Y, Sato M, Sugawara A, et al. Influence of fat and carbohydrate proportions on the metabolic profile in patients with type 2 diabetes: a meta-analysis. Diabetes Care. 2009;32(5):959-965.

13. Nordmann AJ, Nordmann A, Briel M, Keller U, Yancy WS, Jr., Brehm BJ, Bucher HC. Effects of low-carbohydrate vs low-fat diets on weight loss and cardiovascular risk factors: a meta-analysis of randomized controlled trials. Arch Intern Med. 2006;166(3):285-293.

14. Mensink RP, Katan MB. Effect of dietary fatty acids on serum lipids and lipoproteins. A meta-analysis of 27 trials. Arterioscler Thromb. 1992;12(8):911-919.

15. Miyashita Y, Koide N, Ohtsuka M, Ozaki H, Itoh Y, Oyama T, Uetake T, et al. Beneficial effect of low carbohydrate in low calorie diets on visceral fat reduction in type 2 diabetic patients with obesity. Diabetes Res Clin Pract. 2004;65(3):235-241.

16. Talati R, Baker WL, Pabilonia MS, White CM, Coleman CI. The effects of barley-derived soluble fiber on serum lipids. Ann Fam Med. 2009;7(2):157-163.

17. Anderson JW, Randles KM, Kendall CW, Jenkins DJ. Carbohydrate and fiber recommendations for individuals with diabetes: a quantitative assessment and metaanalysis of the evidence. J Am Coll Nutr. 2004;23(1):517.

18. Zhang J, Li L, Song P, Wang C, Man Q, Meng L, Cai J, et al. Randomized controlled trial of oatmeal consump- tion versus noodle consumption on blood lipids of urban Chinese adults with hypercholesterolemia. Nutr J. 2012;11:54.

19. Singh RB, Rastogi SS, Singh NK, Ghosh S, Gupta S, Niaz MA. Can guava fruit intake decrease blood pressure and blood lipids? J Hum Hypertens. 1993;7(1):3338.

20. Singh RB, Rastogi SS, Singh R, Ghosh S, Niaz MA. Effects of guava intake on serum total and high-density lipoprotein cholesterol levels and on systemic blood pressure. Am J Cardiol. 1992;70(15):1287-1291.

21. Zhang MY, Huang CY, Wang X, Hong JR, Peng SS. The effect of foods containing refined Konjac meal on human lipid metabolism. Biomed Environ Sci. 1990;3(1):99105.

22. Riccardi G, Rivellese AA, Giacco R. Role of glycemic index and glycemic load in the healthy state, in prediabetes, and in diabetes. Am J Clin Nutr. 2008;87(1):269S274S.

23. Jenkins DJ, Wolever TM, Taylor RH, Barker H, Fielden $\mathrm{H}$, Baldwin JM, Bowling AC, et al. Glycemic index of foods: a physiological basis for carbohydrate exchange. Am J Clin Nutr. 1981;34(3):362-366.

24. Jenkins DJ, Wolever TM, Taylor RH, Barker HM, Fielden $\mathrm{H}$, Jenkins AL. Effect of guar crispbread with cereal products and leguminous seeds on blood glucose concentrations of diabetics. Br Med J. 1980;281(6250):12481250.

25. Foster-Powell K, Holt SH, Brand-Miller JC. International table of glycemic index and glycemic load values: 2002. Am J Clin Nutr. 2002;76(1):5-56.

26. Liu S, Manson JE, Stampfer MJ, Holmes MD, Hu FB, Hankinson SE, Willett WC. Dietary glycemic load assessed by food-frequency questionnaire in relation to plasma high-density-lipoprotein cholesterol and fasting plasma triacylglycerols in postmenopausal women. Am J Clin Nutr. 2001;73(3):560-566.

27. Goff LM, Cowland DE, Hooper L, Frost GS. Low glycaemic index diets and blood lipids: a systematic review and meta-analysis of randomised controlled trials. Nutr Metab Cardiovasc Dis. 2013;23(1):1-10.

28. Choi H, Song S, Kim J, Chung J, Yoon J, Paik HY, Song Y. High carbohydrate intake was inversely associated with high-density lipoprotein cholesterol among Korean adults. Nutr Res. 2012;32(2):100-106.

29. Murakami K, Sasaki S, Takahashi Y, Okubo H, Hosoi Y, Horiguchi H, Oguma E, et al. Dietary glycemic index and load in relation to metabolic risk factors in Japanese female farmers with traditional dietary habits. Am J Clin Nutr. 2006;83(5):1161-1169.

30. Amano Y, Kawakubo K, Lee JS, Tang AC, Sugiyama $\mathrm{M}$, Mori K. Correlation between dietary glycemic index and cardiovascular disease risk factors among Japanese women. Eur J Clin Nutr. 2004;58(11):1472-1478. 